\title{
PENGARUH MODEL PEMBELAJARAN KOOPERATIF TIPE GROUP INVESTIGATION (GI) UNTUK MENINGKATKAN HASIL BELAJAR SISWA PADA MATERI POKOK SUHU DAN KALOR Derlin Lumbantorua dan Makmur Sirait
}

\author{
Jurusan Fisika FMIPA Universitas Negeri Medan \\ Jalan Willem Iskandar Pasar V Medan, Sumatera Utara \\ derlinlumbantoruan9@gmail.com
}

\begin{abstract}
ABSTRAK
Penelitian ini bertujuan untuk mengetahui pengaruh model pembelajaran kooperatif tipe Group Investigation (GI) terhadap hasil belajar fisika siswa pada materi pokok suhu dan kalor. Jenis penelitian ini adalah quasi exsperiment dengan populasi seluruh siswa kelas $\mathrm{X}$ SMA Negeri 1 Perbaungan yang berjumlah 8 kelas. Sampel penelitian ini terdiri dari 2 kelas yang ditentukan dengan teknik cluster random sampling, yaitu Kelas X-2 sebagai kelas eksperimen dengan menggunakan model pembelajaran Kooperatif Tipe GI dan kelas X-6 sebagai kelas Kontrol dengan menggunakan pembelajaran konvensional, jumlah siswa masing-masing kelas 40 orang. Instrumen yang digunakan dalam penelitian ini ada dua, yaitu tes hasil belajar dalam bentuk pilihan berganda yang telah dinyatakan valid oleh validator dan lembar observasi aktivitas belajar siswa. Menguji hipotesis digunakan uji t, setelah uji persyaratan dilakukan yaitu uji normalitas dan homogenitas. Berdasarkan hasil uji hipotesis menggunakan uji t diperoleh ada pengaruh yang signifikan dari model pembelajaran kooperatif tipe Group Investigation (GI) terhadap hasil belajar fisika siswa pada materi pokok suhu dan kalor di kelas X Semester II SMA Negeri 1 Perbaungan T.P.2015/2016.
\end{abstract}

Kata kunci : Kooperatif tipe GI, hasil belajar, suhu dan kalor

\begin{abstract}
The study aimed to determine the effect of cooperatif learning model investigation group for student learning outcomes in the subject matter of temperature and heat. this kind of research is quasi experiment with a population of the entire population of class $X$ High School N.1 Perbaungan, amounting to 8 classes. the study sample consisted of two classes are determined by random cluster sampling technique that is class X-2 as the experimental class using cooperative learning model type GI and X-6 as the control class using conventional learning, the number of students in each class of 40 people. instrument model used in this study was twofold achievement test in the form of multiple-choice has been declared valid by the validator and observation sheet student learning activities. hypothesis test, $t$ test, after test requirements do is test of normality and homogeneity. based on the results of hypothesis testing using $t$ test obtained no significant effect of GI cooperatif learning outcomes of students in the subject matter and hot temperatures in the class X High School N.1 Perbaungan T.P2015/2016
\end{abstract}

Keywords: Cooperative GI, Learning Outcomes, temperature and heat

\section{PENDAHULUAN}

Pendidikan adalah salah satu bentuk perwujudan kebudayaan manusia yang dinamis dan syarat perkembangan suatu bangsa. Perubahan atau perkembangan pendidikan adalah hal yang seharusnya terjadi sejalan dengan perubahan budaya kehidupan. Pendidikan yang mampu mendukung pembangunan dimasa mendatang adalah pendidikan yang mampu mengembangkan potensi peserta didik, sehingga yang bersangkutan mampu 
menghadapi dan memacahkan probela kehidupan yang dihadapikan (Trianto, 2011).

Tujuan dari pendidikan antara lain meningkatkan iman dan taqwa kepada Tuhan Yang Maha Esa, proses pendewasaan anak didik melalui suatu interaksi, serta memiliki akhlak mulia, mengembangkan potensi peserta didik agar memiliki kemampuan berpikir yang tinggi, meningkatkan kualitas pendidikan. Proses pendidikan dilakukan oleh pendidik dengan sadar, sengaja, dan penuh dengan tanggung jawab untuk membawa anak didik menjadi dewasa jasmaniah maupun berpikir, bersikap, berkemauan secara dewasa, dan dapat hidup wajar selamanya serta berani bertanggung jawab atas sikap dan perbuatannya kepada orang lain (Sugiono, 2008).

Bentuk konkrit dari pendidikan yang dilakukan tampak dalam pembelajaran, yaitu proses komunikasi dua arah, belajar dilakukan oleh peserta didik sedangkan mengajar dilakukan oleh pihak guru sebagai pendidik. Guru sebagai pendidik memegang peranan penting dalam meningkatkan pendidikan, karena dalam mengajar guru bukan saja sebagai fasilitator tetapi juga sebagai pembimbing. Kegiatan interaksi pembelajaran guru secara tidak langsung membina siswa memiliki kemampuan dan memperluas pelajaran.

Fisika salah satu cabang IPA merupakan suatu ilmu pengetahuan yang mempelajari gejala-gejala alam dan interaksi di dalamnya. Pelajaran fisika lebih menekankan pada pemberian langsung untuk meningkatkan kompetensi agar siswa mampu berpikir kritis dan sistematis dalam memahami konsep fisika, sehingga siswa memperoleh pemahaman yang benar tentang fisika. Pemahaman yang benar akan pelajaran fisika akan sangat berpengaruh terhadap hasil belajar siswa, akan tetapi, pada kenyataannya hasil belajar peserta didik pada pembelajaran fisika masih sangat rendah.

Berdasarkan pengalaman penulis saat mengikuti Program Pengalaman Lapangan Terpadu (PPLT), bahwa dalam kegiatan belajar mengajar pada materi fisika, siswa lebih banyak diberikan teori-teori, rumusrumus dan cara menyelesaikan soal-soal fisika tanpa mengarahkan siswa untuk memahami konsep fisika yang sebenarnya, padahal pemahaman yang benar dan mendalam terhadap pelajaran fisika akan sangat mempengaruhi hasil belajar siswa. Pemberian teori-teori dan cara penyelesaian soal-soal saja kepada siswa menyebabkan siswa menjadi tidak aktif dan kreatif saat mengikuti pembelajaran fisika. Siswa menjadi menganggap pelajaran fisika itu hanya sekedar hafalan rumus-rumus dan penyelesaian soal-soal, saat disajikan soalsoal yang berkaitan dengan masalahmasalah fisika dalam kehidupan sehari, beberapa siswa jadi bingung untuk menyelesaikan soal tersebut. Dampaknya saat dilakukan ujian ataupun ulangan, nilai siswa menunjukkan bahwa hasil belajar siswa tersebut rendah.

Hasil observasi yang dilakukan peneliti di SMA Negeri 1 Perbaungan dengan menyebarkan angket kepada siswa, diperoleh data bahwa dari 40 siswa, 60\% mengatakan tidak menyukai Fisika, 21\% menyukai Fiska. Selain itu 19\% siswa mengatakan Fisika itu membosankan. Peneliti juga melakukan wawancara dengan guru bidang studi fisika yang mengatakan bahwa metode yang diterapkan adalah metode ceramah, tanya jawab dan kadangkadang menggunakan demonstrasi jika alat yang digunakan mudah dicari dan sesuai dengan materi yang diajarkan. Proses belajar mengajar di ruangan kelas, guru menjelaskan pelajaran di depan kelas dan memberikan ringkasan materi dengan mencatatnya di papan tulis dan siswa menyimak penjelasan guru serta mencatat hal penting dari materi yang diajarkan. Hasil belajar yang dicapai siswa juga tergolong rendah, $40 \%$ siswa yang dapat memenuhi standar nilai ketuntasan 
minimum yaitu 72, sehingga harus dilakukan remedial agar seluruh siswa dapat dinyatakan tuntas terhadap materi yang dipelajari

Permasalahan siswa yang merasa sulit dan bosan terhadap pelajaran fisika perlu diupayakan pemecahannya yaitu dengan melakukan tindakan-tindakan yang dapat merubah suasana pembelajaran yang melibatkan siswa. Aktifnya siswa dalam pembelajaran saat pembelajaran akan lebih bermakna, karena siswa secara langsung diajak untuk mengkonstruksi pengetahuan tersebut dan membina kerjasama antara siswa yang pandai dan kurang pandai, siswa dituntut dalam bentuk kelompok yang bersifat heterogen.

Pembenahan yang dapat dilakukan oleh seorang guru dalam mengatasi pembelajaran teacher centered learning antara lain guru harus mampu berinteraksi secara baik dengan siswa sehingga guru bukan hanya sebagai pusat pemberi informasi melainkan sebagai fasilitator untuk siswa. Guru harus mampu memilih model pembelajaran yang tepat dalam menyampaikan setiap pembelajaran yang diajarkan agar pembelajaran berubah menjadi student centered learning. Model pembelajaran yang memberi kesempatan kepada siswa untuk terlibat secara aktif dalam pembelajaran adalah model pembelajaran kooperatif tipe group investigation (GI). Rusman, (2014), menyatakan model pembelajaran kooperatif tipe GI adalah salah satu model pembelajaran inovatif yang dapat mendorong siswa untuk ikut aktif dalam belajar fisika. Model ini merupakan cara belajar-mengajar yang lebih menekankan pada pemahaman materi yang diajarkan guru dengan menyelesaikan soal-soal.

Aplikasi model pembelajaran koopertatif tipe GI dapat memotivasi siswa memanfaatkan seluruh energi sosial siswa, saling mengambil tanggung jawab. Model pembelajaran kooperatif yang digunakan adalah tipe GI, dimana model pembelajaran kooperatif tipe GI dirancang oleh Herbert Thelen. Model pembelajaran kooperatif tipe group investigation ini dapat menyiapkan siswa untuk berpikir logis, kritis, kreatif, serta berargumentasi di depan kelas dengan baik (Arends, 2008).

\section{TUJUAN PENELITIAN}

Penelitian ini bertujuan untuk mengetahui pengaruh model pembelajaran kooperatif tipe Group Investigation (GI) terhadap hasil belajar fisika siswa pada materi pokok suhu dan kalor

\section{METODE PENELITIAN}

Penelitian ini adalah penelitian quasi eksperimen. Populasi penelitian ini adalah seluruh siswa kelas $\mathrm{X}$ SMA yang terdiri dari 8 kelas. Sampel penelitian dilakukan dengan cara tehnik acak kelas (cluster random sampling) sebanyak dua kelas. Dimana kelas pertama dijadikan kelas eksperimen (kelas X2) dengan menggunakan model pembelajaran kooperatif tipe Group Investigation dan kelas kedua dijadikan kelas kontrol (kelas X6 ) dengan pembelajaran konvensional. Jumlah siswa masing-masing tiap kelas 40 orang.

Peneliti melakukan tes untuk mengetahui hasil belajar fisika siswa pada kedua kelas sebelum dan sesudah diberikan perlakuan. Desain penelitian yang digunakan desain two group pretestposttest design.

Data yang diperoleh ditabulasikan kemudian dicari rata-ratanya. Sebelum dilakukan analisis data, terlebih dahulu ditentukan nilai masing-masing kelompok sampel lalu dilakukan pengolahan data dengan langkah-langkah sebagai berikut yakni; menghitung nilai rata-rata dan simpangan baku, uji normalitas menggunakan uji Lilliefors, uji homogenitas menggunakan uji $\mathrm{F}$, pengujian kesamaan rata-rata pretes menggunakan uji $\mathrm{t}$ dua pihak dan pengujian hipotesis menggunakan uji t satu pihak pada data postes.

\section{HASIL DAN PEMBAHASAN Hasil Penelitian}


Sebelum dilakukan perlakuan pada penelitian terlebih dahulu diberikan tes pendahuluan untuk mengetahui kemampuan awal siswa pada kedua kelompok sampel. Berdasarkan data yang diperoleh nilai ratarata petest kelas kontrol sebesar 36,75 dengan standar deviasi 10,47 sedangkan nilai rata-rata pretes pada kelas eksperimen sebesar 37,13 dengan standar deviasi 11,92. Peneliti memberikan perlakuan yang berbeda, nilai rata-rata kelas yang diperoleh kelas kontrol dengan model pembelajaran konvensional adalah 54,88 dengan standar deviasi 9,77 sedangkan nilai rata-rata pada kelas eksperimen dengan model pembelajaran kooperatif tipe GI adalah 70,75 dengan standar deviasi 10,89. Hal ini berarti hasil belajar siswa pada kelas kontrol mengalami peningkatan sebesar 18,13 dan pada kelas eksperimen sebesar 33,62 .

Hasil pretes kedua kelas dapat dilihat pada gambar 1

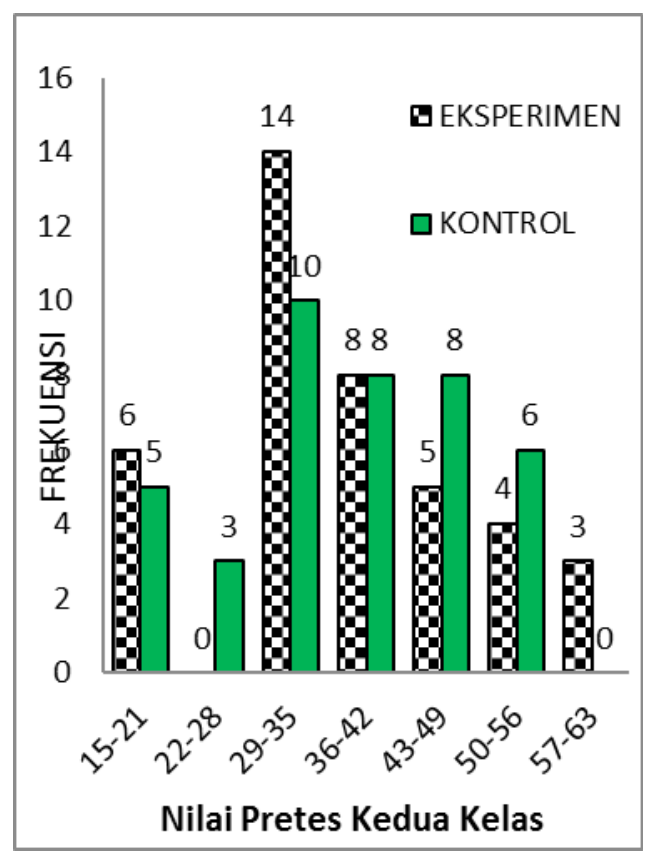

Gambar 1. Diagram Batang Data Pretes Kelas Eksperimen dan Kelas Kontrol

Hasil postes kedua kelas dapat dilihat pada gambar 2

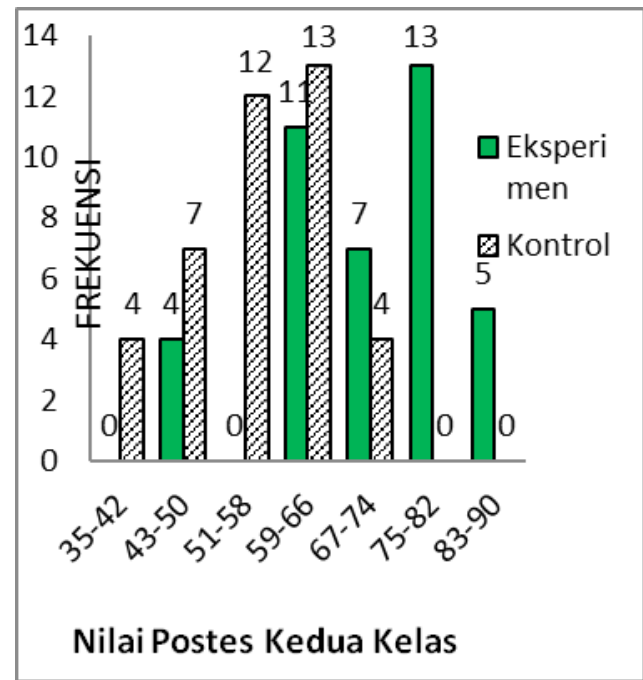

Gambar 2.Diagram Batang Data Postes Kelas Eksperimen dan Kelas Kontrol.

Kriteria uji normalitas adalah apabila $\mathrm{L}_{\text {hitung }}<\mathrm{L}_{\text {tabel }}$ dengan $\alpha=0,05$ dapat diartikan data berdistribusi normal. Berdasarkan hasil uji normalitas dengan uji Lilliefors data pretes menunjukkan bahwa pada kelas eksperimen $\mathrm{L}_{\mathrm{o}}<\mathrm{L}_{\text {tabel }}$ atau $0,1049<0,1401$ dan kelas kontrol $\mathrm{L}_{\mathrm{o}}<\mathrm{L}_{\text {tabel }}$ atau $0,1028<0,1401$, dapat diartikan bahwa data hasil pretes berdistribusi normal. Uji homogenitas menggunakan uji $\mathrm{F}$ untuk data pretes diperoleh bahwa $\mathrm{F}_{\text {hitung }}<\mathrm{F}_{\text {tabel }}$ yaitu $1,296<1,705$ dengan $\alpha=0,05$, maka diartikan bahwa data pretes homogen. Setelah data normal dan homogen maka dapat dilakukan uji kesamaan rata-rata menggunakan uji t dua pihak. Berdasarkan hasil uji $t$ dua pihak didapat bahwa kemampuan awal siswa sama. Peneliti memberikan perlakuan yang berbeda di mana pada kelas eksperimen diberikan pembelajaran dengan menggunakan model pembelajaran kooperatif tipe GI sedangkan pada kelas kontrol diberikan pembelajaran konvensional. Model pembelajaran kooperatif tipe GI diterapkan pada kelas 
eksperimen diperoleh bahwa nilai rata-rata postes kelas eksperimen adalah 75,75 dengan simpangan baku 10,89. Sedangkan pada kelas kontrol yang diterapkan pembelajaran konvensional adalah 54,88 dengan simpangan baku 9,77.

Hasil uji normalitas data postes diperoleh bahwa Lo $<\mathrm{L}_{\text {tabel }}$ yaitu $0,0775<0,1401$ untuk kelas eksperimen dan $0,1191<0,1401$ untuk kelas kontrol, sehingga dapat diartikan bahwa data hasil postes berdistribusi normal. Hasil uji $\mathrm{F}$ data postes diperoleh bahwa $F_{\text {hitung }}<F_{\text {tabel }}$ yaitu $1,242<1,705$ dengan $\alpha=0,05$ maka diartikan bahwa data postes homogen.

Pengujian hipotesis untuk data pretes diuji dengan uji $t$ dua pihak nilai rata-rata untuk kelas eksperimen adalah 37,13 dan nilai rata-rata kelas kontrol adalah 36,75 . Hasil pengujian hipotesis dua pihak $t_{\text {hitung }}>\mathrm{t}_{\text {tabel. }}$. Harga $0,151<1,994$, berarti kemampuan awal siswa pada kelas eksperimen sama dengan kemampuan awal siswa pada kelas kontrol pada materi suhu dan kalor.

Pengujian hipotesis untuk data postes diuji dengan uji t satu pihak. Nilai rata-rata postes kelas eksperimen adalah 75,75 dan kelas kontrol adalah 54,88. Hasil pengujian hipotesis $t_{\text {hitung }}>t_{\text {tabel. }}$. Harga $6,852>1,667$, berarti hasil belajar menggunakan model pembelajaran kooperatif tipe Group Investigation (GI) lebih baik dari model pembelajaran konvensional pada materi pokok suhu dan kalor atau ada pengaruh yang signifikan model pembelajaran kooperatif tipe Group Investigation terhadap hasil belajar siswa pada materi pokok suhu dan kalor.

\section{Pembahasan}

Model kooperatif tipe GI dapat mempengaruhi hasil belajar memberikan kesempatan kepada siswa untuk saling bekerja sama dan memberikan pendapat sehingga proses belajar tidak terkesan kaku. Model kooperatif tipe GI juga memberi kesempatan kepada anggota kelompok untuk mengambil bagian dalam merencanakan berbagai dimensi dan tuntutan dari proyek mereka. Hal ini juga didukung oleh hasil penelitian Simanjuntak dan Siregar (2014), yang menyatakan perbedaan yang signifikan kemampuan pemecahan masalah fisika siswa di kelas eksperimen adalah rata-rata sebesar 71,88 dengan kualifikasi tinggi sedangkan nilai rata-rata siswa di kelas kontrol adalah 49,76 dengan kualifikasi kurang.

Model pembelajaran kooperatif tipe GI juga dapat meningkatkan aktivitas belajar siswa.

Hal ini didukung oleh penelitian Harapan dan Turnip (2014) menyatakan adanya peningkatan aktivitas belajara siswa saat model pembelajaran kooperatif tipe GI karena siswa akan lebih aktif saat proses belajar.

Hasil observasi aktivitas siswa kelas eksperimen dan kelas kontrol yang diajarkan menggunakan model pembelajaran kooperatif tipe GI dan konvesional dapat dibedakan, dimana, nilai aktivitas kedua kelas sampel juga sangat berbeda, hal ini terjadi karena dikelas eksperimen yang menonjol unsur kerja sama antar siswa. Perkembangan aktivitas pada kelas eksperimen dari pertemuan I,II,III,dan IV diperoleh rata-rata perkembangan aktivitas 60,42; 70,94 ; 80,$60 ; 91,15$ semakin naik mulai dari kategori Sedang hingga Tinggi. Dengan demikian model pembelajaran kooperatif tipe GI mempengaruhi aktivitas siswa. Sedangkan pada kelas kontrol aktivitas siswa dari pertemuan I,II,III,dan IV diperoleh rata-rata perkembangan aktivitas 62,11 tidak mengalami kenaikkan.

Model konvensional yang dilaksanakan dalam kelas kontrol cenderung menempatkan siswa untuk bekerja secara individu sehingga kesempatan untuk saling berbagi dan berdiskusi antar sesama siswa menjadi terhambat hal inilah yang membuat siswa kurang kompak dan sangat jarang memberi pertanyaan atas hal-hal yang belum diketahui secara pasti. Pembelajaran dengan menggunakan model pembelajaran kooperatif tipe GI menekankan pada 
kesadaran siswa dalam belajar berfikir, aktif melakukan investigation, belajar mengaplikasikan pengetahuan dan keterampiilan serta saling berbagi pengetahuan, konsep, dan keterampilan tersebut kepada siswa yang lainnya. Hal ini didukung oleh Dwi dan Arif (2013) menyatakan model pembelajaran kooperatif tipe GI membuat siswa lebih kreatif.

Walaupun model pembelajaran kooperatif tipe GI mampu meningkatkan aktivitas dan hasil belajar siswa tetapi dalam pelaksanaannya terdapat juga kendala yaitu keterbatasan dalam penyediaan alat dan bahan yang digunakan dalam LKS, sehingga ada beberapa kelompok yang menunggu kelompok lain untuk menggunakan alat dan bahan tersebut. Peneliti mencoba mengatasi kendala ini dengan meminta kelompok lain mengerjakan tugas dalam LKS yang tidak berhubungan dengan alat dan bahan yang sama, namun hasilnya belum maksimal.

Berbeda halnya dengan model pembelajaran konvensional dengan posisi guru sebagai pengatur utama kegiatan siswa. Siswa hanya sebagai penerima informasi dari guru dan guru lebih banyak memberikan penjelasan atau ceramah yang menjadikan siswa hanya pasif, dengan kata lain proses pembelajaran hanya berjalan satu arah. Walaupun guru telah memberikan kesempatan kepada siswa untuk bertanya, namun tetap saja tidak ada muncul pertanyaan dari mereka. Interaksi belajar kurang, hal ini terlihat pada saat mengerjakan latihan siswa enggan untuk bertanya kepada temannya maupun kepada guru tentang penyelesaian soal yang tidak dipahami.

Kendala- kendala dalam penerapan model pembelajaran kooperatif tipe GI selama kegiatan pembelajaran berlangsung, diantaranya yaitu pada saat pembelajaran melalui tahapan pembelajaran guru merasa kesulitan dalam mengorganisir waktu, dalam melaksanakan tahapan kegiatan praktikum masih dihadapi dengan kendala keterbatasan alat-alat praktikum, kemudian pada tahapan presentasi hasil praktikum, siswa masih kurang terbiasa tampil menyampaikan pendapatnya di depan kelas. Siswa masih canggung dalam melaksanakan presentasi sehingga kurang tercipta suasana diskusi antar siswa.

\section{KESIMPULAN DAN SARAN \\ Kesimpulan}

Hasil belajar siswa dengan model pembelajaran kooperatif tipe Group Investigation(GI) sebelum diberikan perlakuan rata-rata pretes sebesar 37,13 dan setelah diberikan perlakuan rata-rata postes siswa sebesar 70,75. Hasil belajar siswa yang menggunakan pembelajaran konvensional sebelum diberikan perlakuan rata-rata pretes sebesar 36,75 dan setelah diberikan perlakuan rata-rata postes siswa sebesar 54,88. Aktivitas belajar siswa kelas Eksperimen mengalami peningkatan selama kegiatan pembelajaran berlangsung setiap pertemuan dengan rata-rata peningkatan $76,28 \%$, aktivitas belajar siswa kelas Kontrol tidak mengalami peningkatan dari setiap pertemuan. Ada pengaruh yang signifikan dari penggunaan model pembelajaran kooperatif tipe GI terhadap hasil belajar siswa pada materi Suhu dan Kalor .

\section{Saran}

Kepada guru ataupun calon guru yang berencana menggunakan model pembelajaran pada saat melakukan percobaan waktu banyak terbuang karena siswa belum memahami langkah-langkah percobaan. Diharapkan guru harus terlebih dahulu mendemonstrasikan langkahlangkah percobaan yang akan dilakukan siswa agar siswa paham. Sebelum model ini diterapkan, sebaiknya memahami terlebih dahulu tiap fase atau sintaks dari model pembelajaran kooperatif tipe GI sehingga model pembelajaran ini dapat diterapkan dengan benar. Kondisi kelas akan selalu ribut bila tidak diberi penegasan sehingga dapat mengurangi efektivitas belajar dalam kelas, guru bisa lebih tegas dalam memberikan tugas terhadap siswa, agar 
pembelajaran yang berjalan lebih kondusif dan berjalan sesuai dengan rencana pembelajaran yang sudah dirancang.

\section{DAFTAR PUSTAKA}

Arends, R., (2008), Learning To Teach, Pustaka Pelajar, Yogyakarta.

Dwi, I.M., Arif,H.,(2013), Pengaruh Model Pembelajaran Kooperatif Tipe Group Investigation (GI) Berbantuan Media Komputer terhadap Hasil Belajar Siswa pada Materi Pokok Listrik Dinamis Jurnal Pendidikan Fisika Indonesia 2(4):97-104

Harahap, R, dan Turnip, B., (2014), Pengaruh Model Pembelajaran Kooperatif TipeGroup Investigation (GI) Berbantu Media Flash Terhadap Hasil Belajar Fisika Siswa SMA,Jurnal Inovasi Penelitian Fisika 2(3), 156-163

Rusman, (2014), Model-model Pembelajaran, Rajawali Pers, Jakarta

Simanjuntak, S, dan Siregar, N.,(2014), Pengaruh Model Pembelajaran Kooperatif Tipe Group Investigation terhadap Hasil Belajar pada Materi Listrik Dinamis, Jurnal Inovasi Penelitian Fisika, 2( 2), 171-179

Slavin., (2009), Cooperatif Learning, Nusa Media, Bandung.

Sudjana., (2005), Metoda Statistika, Tarsito, Bandung.

Sugiono., (2008), Metode Penelitian Pendidikan, Alfabeta, Bandung.

Trianto., (2011), Mendesain Model Pembelajaran Inovatif-Progressif: Konsep, Landasan, dan Implementasinya pada Kurikulum Tingkat Satuan Pendidikan (KTSP), Kencana, Jakarta. 